\title{
The Women-Owned Enterprises in India: \\ Condition, Performance and Challenges
}

\author{
Soumen Ghosh ${ }^{\mathbf{1}}$; Srija Mitra ${ }^{2}$
}

\begin{abstract}
:
Purpose: The aim of this paper is to investigate the condition of the Women-owned micro and small-scale enterprises, their performances and the challenges faced by the women owner in the Indian context.

Design/Methodology/Approach: The condition of the overall Women-owned micro and smallscale enterprise has portrayed by the simple table and diagram. In addition, we have used a simple multivariate regression model to understand the performance difference of these enterprises across Sector using the National Sample Survey (NSS) 73rd round microdata.

Findings: The study finds that the proportion of women-owned enterprises are significantly low. Interestingly, in both the sectors (i.e. Rural \& Urban), Women-owned Enterprises are mostly operated as Own-account segment (OAE) within the household premises. The Rural Sector is much isolated in terms of the enterprise's performance. Some major problems like Demand shortage, non-recovery of financial dues, Non-availability of Credit, shortage of Raw materials etc. are facing by the Women owners during their operation.
\end{abstract}

Originality/Value: The study pinpoints the condition and overall position of Women-owned micro and small-scale enterprises in India. Further, it suggests that the government can put extra attention to encourage women to enter into the sphere of leadership.

JEL Classification: J01, J21, E26, J46, J54, J82

Keywords: Women-Owned Enterprises, Human Development, Micro and Small Scale Enterprises, Informal Sector, Self-Employment.

\footnotetext{
${ }^{1}$ Research Scholar, Tata Institute of Social Sciences, Mumbai, Maharashtra, India.

${ }^{2}$ Research Scholar, Centre for Economic and Social Studies, Hyderabad, Telengana, India.
}

\section{Corresponding Author:}

Soumen Ghosh, Research Scholar, Tata Institute of Social Scinces, Mumbai, Maharashtra, India.

Email: soumen.eco@live.com 


\section{Introduction}

The notion of 'human development' is about the equal opportunities of all spheres of the people who can enlarge their choices, identify their potentials and enjoy their lives with utmost dignity and freedom. The main focus of human development is to secure equal opportunities for both men and women which is in the core of the process. Similarly, Amartya Sen's 'capability approach' emphasized the much wider approach of development where the human 'well being' is in the centre (Sen, 2017). As a result, the objective of the development planning has shifted its focus from achieving only higher economic growth to that of enhancing human development. To enhance sustainable and far-reaching human development, a country requires an 'inclusive growth strategy'.

So far as the development scenario of India is concerned, although the economy has been crossing the significant economic growth of above 6 Percent scale, from the late ' $80 \mathrm{~s}$, still this higher growth has never been 'inclusive' in nature, as, in the post-liberalization era, India has experienced 'jobless growth'. From the last two decades, it has observed that the major share of economic growth is generating from the formal sector while the majority of the labour force is employed in the Informal sector (NCEUS, 2007; Paul GD, Achar, Muniyoor, \& Venkatesh Murthy, 2017). According to Economic Survey 2018-19, above 90\% of the total labour force in India is engaged in different kind of informal activities.

From the last few decades, an ample amount of literature has discussed the different aspects of the informal sector and its characteristics. Despite the voluminous literature exists which has focused on the informal sector in general, the condition of women-headed informal micro and small enterprises has not got sufficient attention. In the existing literature, genderinclusive growth did not get any consideration despite the fact that the women are serving a 
significant proportion of the total work (Chen, 2011). Although, in the last decade, it is much prominent that women are becoming more into the domain of wage employment. It has also considered that women-owned enterprises (WOE) are recognized as 'a crucial way to fight against poverty and gender inequity in society and act as a vehicle in the promotion of empowerment and leadership among women' (Elson et al., 2000). Thus, WOE can take a major role in the socio-economic development of the economy. Nevertheless, in a country like India, it is not so easy to prosper and grow the enterprises, which are operate by women because of existing socio-economic-cultural obstacles. Therefore, in this paper, we are trying to portray the condition of the WOE in India and look into their performance and the challenges they are facing during their operation. This paper could be an addition to the literature of the informal sector to examine, how far the informal economy is successful in achieving gendered inclusiveness'. The key focus of this paper is to identify the performance of women-owned informal enterprises in the Indian scenario from the latest NSS $73^{\text {rd }}$ round microdata (201516). Along with this, we have tried to compare the performance differences of WOE across sectors.

Given this background, section 2 provides a brief literature survey; this is followed by the section 3 that discusses the data and methodology of the study. The next section looks into the overall picture of WOE in Indian context from microdata with using descriptive tables and graphical representation. This paper as it has mentioned in the earlier section also considers these aspects we have a look into some descriptive and advanced statistical analysis. The concluding section presented at the end.

\section{Literature Review}

Over the last few decades, the informal sector is accommodating a majority of the labour force across the globe and getting central attention from the policymakers as well as the 
researchers. The informal sector indulging a substantial amount of employment opportunity for both men and women in every part of the world. However, an ample amount of research has already been done to get the broader idea of the informal sector; the position of women in this sector is still much under-researched. Unquestionably, women's shares of the total labour force engaged in informal activities (excluding agriculture) are much higher than its male counterparts (Elson et al., 2000). Howbeit, they are mostly engaged as either unpaid labourers or self-employed. For instance, in India, nine out of every ten women, working in the informal sector (Chen, 2011). However, in this particular paper, we are focusing on the women as an owner of the informal enterprises, rather than as a labourer. Like most of the developing countries, only $20 \%$ of informal firms are owned by women in spite of the fact that a majority of the female workforce is part of the Informal Sector in India. Both Human Development Index rank (130 in 2018) and the value of Gender Development Index (0.841 in 2017) exemplify the low human development and high gender inequality in India. Even it is observed that gender inequality preponderantly exists in the informal sector (Agarwala, 2011). Here we have come up with the overall condition and performance of the WOE and the problems faced by the firms in the Indian context.

The existing literature of Asian Countries suggests that from the view of the motivation behind being an entrepreneur, we can divide it into three categories ${ }^{3}$. Women in India get less access to education, thus they are unable to participate in the formal sector and as an alternative, and they take up self-employment (Ghosh \& Cheruvalath, 2007; Tambunan, 2009). Thus, most of the WOEs are own account enterprises in India.

\footnotetext{
${ }^{3}$ Chance Entrepreneurs, who start a business without any goal or proper plans and their hobbies ultimately transformed into a business. Created entrepreneurs are either pulled into entrepreneurship out of choice - like the desire to be independent or to try doing something by themselves, they are moved to this choice. A study finds that only one-fifth of women are drawn to entrepreneurship by pulled factors. Forced entrepreneurs become an entrepreneur compelled by the circumstances (e.g. financial difficulties faced by the family, demise of the spouse) (Tambunan, 2009)
} 
In most of the developing countries, women entrepreneurs face some kinds of socioeconomic constraints. The major difficulty which generally women entrepreneurs face is the 'access to financial assistance'. The women face hurdles to get loans from financial institutions due to two reasons; firstly, they do not have property on their name so they cannot use the property as collaterals; secondly, the financial institutions have a preconceived notion that the women entrepreneurs are less likely to repay the loan, so they discourage the women borrowers (Bushell, 2008; Gurnani, 2014; Unnikrishnan.P, 2016). Thus, women entrepreneurs face a limitation while borrowing from financial institutions. As a result, the women have no option but to get a loan from the local moneylender at a high-interest rate and get trapped into the vicious circle of debt, which acts as a major constraint on their performance. However, we think that nowadays, this problem may not be considered as a major one in India due to the rapid expansion of microcredit.

The lower female literacy is a key characteristic of the global south which is caused by a lack of formal education among them. Given this backdrop, they are generally less aware of the government policies and regulation on how the formal institutions can play a major role to help them in their business. Apart from this, they also have less knowledge about the market condition and new technologies. These may increase their cost of production and become hard to compete with other firms which can act as a barrier to the growth of their business (Bushell, 2008). Due to lack of (formal) education, the women entrepreneurs are also less self-confident which ultimately reduces the ability of women entrepreneurs to endure the risk involved in operating an enterprise and Risk-bearing is an essential indispensable for an effectual entrepreneur (Unnikrishnan.P, 2016). In spite of all these constraints, less educated women have a greater probability to be an entrepreneur as they are not absorbed in the formal sector (Ghosh \& Cheruvalath, 2007). 
Women entrepreneurs have faced some kind of socio-cultural constraints due to the existence of patriarchal framework. It is taken for granted that the women family member(s) should do all the household works. As a result of that, women are used to facing a time constraint. Sometimes, for women entrepreneur, family and personal obligations become stumbling blocks in the path of a successful business. It becomes very difficult for women to use time optimally so that, they can manage both business and home efficiently (Gurnani, 2014; Perwej, 2012). Due to the lack of mobility and education, WOEs does not have large market networks. The networks are mainly based on face to face communication among the dealers and convincing the customers to promote their products. As a result of that, most of the women entrepreneurs operate in their "comfort zones"; i.e. they operate among the known clients like family and friends or supply to the people who are known through family or other close relatives (Bushell, 2008; Timmons, 2006). So they are unable to market their products in a broader range which also acts as a constraint towards the growth of their enterprises. They also face tough competition in the matter of marketing their products from the organized sector as well as the male-owned enterprises (Unnikrishnan.P, 2016). Thus, more often, the women entrepreneurs have to depend on the middlemen, which also increase the operational cost of the enterprise. The women entrepreneurs do not act as per the changing market conditions as they are less aware of that, and hence cannot effectively expand their business (Perwej, 2012). Like other developing countries, the aforementioned facts are barriers in the path of successful women entrepreneurs in India. In this present study, we are trying to analyse and discuss the performance of the Women-owned enterprises in India and the factors behind its poor performance along with probably firm level barriers.

\section{Data \& Methodology}

This particular study is based on secondary data analysis. Here, we have broadly used the National Sample Survey Organization (NSSO) $73^{\text {rd }}$ round micro database (2015-16) for the 
analysis. The total estimated 1,23,85,129 Enterprises from a sample of 35,327 Women-Owned Unorganised Enterprises have extracted and used in our analysis. We concentrated to depict the condition of the WOE across the sector for their distinct nature. Both manufacturing and service activities have considered across all states and union territories in India for our analysis. We have considered only those enterprises who have the strength of the highest 20 total labour. The entire analysis comprises of four major social groups i.e. SC, ST, OBC \& Others. We are not considering missing values and undefined values in our analysis.

However, in the first part of the analysis, we have tried to portray the overall picture of the WOE through simple tables and diagrams. Those diagrams are showing the share of WOE across the sector, enterprise type, a social group of the owner, location of the enterprises etc. In the later section, we have tried to show the performance of the enterprises (both Rural and Urban Sector) in terms of its gross value added. Here we have taken Gross Value added as the indicator for the performance of the enterprises. To standardize the variables we have taken per capita form i.e. per capita gross value added. To compare the performance of these two categories, we have used independent T-test for the mean difference between these two distinct sectors. In the next section, we have executed the Simple linear regression model to get the overall firm-level effects on the enterprise's performance. we have also checked the post hoc tests of both the regression models to see whether the model is satisfying Ordinary least square (OLS) or not. In this entire study, we have tried to exhibit a clear picture of Women-owned enterprises in the Indian context.

\section{Women-Owned Enterprises: an overview}

In this section, we are trying to portray the overall picture of WOE using NSSO microdata in Indian Context. From the microdata, it has observed that only one-fifth of the total enterprises are owned by the women in India. The main reason behind that poor result of WOE 
is the majority of the women involved in domestic/household work as well as unpaid work in the enterprises. The share of WOE in both the rural and urban sectors are 55.6 and 44.4 respectively. Strikingly, the data showing us that rural women are much forwardly getting into the ownership of enterprises. Now we will see the different aspect of WOE across sectors and the share of enterprises has calculated column-wise in each item. Let us first start with the social group-wise classification of WOE. From table 1.1, in the rural sector, WOEs are concentrated among Other Backward Caste (OBC) whereas it is lowest for Scheduled Tribe (ST). The proportion of rural Unreserved ${ }^{4}$ (UR) WOE is one-fourth of the total WOE. In a similar manner, the maximum number of WOE in urban area are concentrated among the OBC whereas it is lowest for the SC owners. Surprisingly, the women of SC and ST communities have a higher proportion of ownership in rural areas compared to urban counterpart.

From the definition of the NSSO, enterprises are classified into two distinct categories i.e. Own Account Enterprises \& Establishment. Own Account Enterprises (OAE) are those kinds of the firm which do not hire any outside labour for their production process and this segment is also known as 'self-employment'. On the contrary, relatively bigger enterprises those who hire at least one labour are called 'Establishment'. This type of enterprises is relatively bigger compared to OAE segment. From the microdata, It is noticed that a majority of the WOE are OAE type of firm in both rural and urban areas. In other words, it can be said that most of the firm in both rural and urban areas are operated with the help of the unpaid family labourers. In the rural sector, a majority of the rural women either engaged with the agricultural activities or engaged in non-farm activities with the help of family members or peer group along with their domestic work. In the rural sector, 98.3 per cent of the total rural WOE is operated as the OAE whereas it is slightly lower (i.e. 93.3\%) for the urban areas.

${ }^{4}$ Unreserved means apart from SC, ST and OBC 
Contrary to this, the establishment segment of WOE is much lower in rural areas compared to urban.

Table 1.1: Proportion of WOE across the social group, enterprise type and location of the enterprise

(in Percentage)

\begin{tabular}{|l|c|c|c|}
\hline & Rurral & Trial \\
\hline Social Group & & & \\
\hline Scheduled Tribe & 6.8 & 2.2 & 4.8 \\
\hline Scheduled Caste & 16.8 & 11.5 & 14.5 \\
\hline Other Backward Caste & 48.8 & 49.9 & 49.3 \\
\hline Unreserved & 26.8 & 35.5 & 30.7 \\
\hline Unknown & 0.7 & 0.9 & 0.8 \\
\hline Enterprise Type & & & \\
\hline Own Account Enterprise & 98.3 & 93.3 & 96.1 \\
\hline Establishment & 1.7 & 6.7 & 3.9 \\
\hline Location of the Firm & & & 84.7 \\
\hline Within Household Premises & 89.9 & 78.2 & 15.3 \\
\hline Outside the Household & 10.1 & 21.8 & \\
\hline Premises & & & \\
\hline
\end{tabular}

Estimated 1,23,85,129 Enterprises from a sample of 35,327 Women-Owned Unorganised Enterprises Source: computed from unit-level data of NSS 73rd Round (2015-16)

Another very important characteristic is the location of these enterprises. Usually, those enterprises which perform the production process outside the households are bigger in terms of firm size and volume of transaction. On the other hand, the enterprises which are situated within the household premises have low possibilities for further expansion because of its limited capacity. In the case of WOE, production is mainly held within the household with the help of the family labourers as the women have to balance this along with their domestic household works. For this reason, the total time has been split into two segments. In fact, the data also showing a similar kind result. If we look into the table 1.1 we can see that among total WOE only 15 per cent of the total WOE are operated their production process outside the household premises and the remaining are operated within the household premises. In the rural area, only 10 per cent of the total WOE are operating their production outside the household 
premises. Contrarily, in the urban area, this proportion is much better. Here one-fifth of the urban WOEs are operated outside their household premises and remaining operates within household premises. In the urban area, the informal enterprises are integrated with formal/modern sector through subcontracting/offshoring this leads to better access to resources of the enterprises. For WOE, this factor leads to get into bigger enterprises. Conversely, the rural sector is much more isolated and the performance of the firms are much poorer than its urban counterpart.

\section{The Performance of Women-Owned Enterprises:}

From the last section, we have already seen that a majority of the WOE operate as Own Account Enterprise or self-employed. These enterprises are mostly smaller size and operating their production process within the household premises with the help of family labour. The motive of these enterprises is to add some more extra earning into the total household income for their better livelihoods and mostly they do not have any plan for further expansion. In this section, we have tried to analyse the performance of the micro and small-scale WOE, probable factors behind the performance and the limitations they are facing during the operation across the sector in the Indian context. First, we have used a simple ANOVA table to cater to our purpose. Then we have run a multiple regression model to find out the probable factors behind this distinct performance of the WOE across sector followed by the discussion of the limitations that facing by the women Owners in their operation.

First, we have used Simple ANOVA table to describe the performances of WOE across the sector. Here is the table below - 
Table 1.2: Descriptive Table and ANOVA for Gross Value Added of WOE in India across the Sector

\begin{tabular}{|c|c|c|c|c|c|c|c|c|}
\hline & \multirow[t]{2}{*}{$\mathrm{N}$} & \multirow[t]{2}{*}{ Mean } & \multirow[t]{2}{*}{$\begin{array}{c}\text { Std. } \\
\text { Deviation }\end{array}$} & \multirow[t]{2}{*}{$\begin{array}{l}\text { Std. } \\
\text { Error }\end{array}$} & \multicolumn{2}{|c|}{$\begin{array}{l}\text { 95\% Confidence Interval for } \\
\text { Mean }\end{array}$} & \multirow[t]{2}{*}{ Minimum } & \multirow[t]{2}{*}{ Maximum } \\
\hline & & & & & Lower Bound & Upper Bound & & \\
\hline Rural & 6877248 & 3098.23 & 7931.827 & 3.025 & 3092.30 & 3104.16 & -59500 & 2098374 \\
\hline Urban & 5491083 & 7350.47 & 20184.409 & 8.614 & 7333.59 & 7367.36 & -55250 & 2086330 \\
\hline Total & 12368331 & 4986.07 & 14843.221 & 4.221 & 4977.80 & 4994.34 & -59500 & 2098374 \\
\hline
\end{tabular}

ANOVA Result for Gross Value Added of WOE in India across the sector

Gross Value Added

\begin{tabular}{|l|r|r|r|r|r|}
\hline & \multicolumn{1}{c|}{ Sum of Squares } & \multicolumn{1}{c|}{ df } & Mean Square & F & Sig. \\
\hline Between Groups & 55207528918019.260 & 1 & 55207528918019.260 & 255758.996 & .000 \\
Within Groups & 2669797884835209.500 & 12368328 & 215857623.184 & & \\
Total & 2725005413753229.000 & 12368329 & & & \\
\hline
\end{tabular}

Estimated 1,23,85,129 Enterprises from a sample of 35,327 Women-Owned Unorganised Enterprises

Source: computed from unit-level data of NSS 73rd Round (2015-16)

To analyse the performance of the WOE, we have used Gross Value Added per Workers as the indicator for the enterprise's performance. Here we have differentiated the performance of WOE across the sector (i.e. Rural and Urban) because of their diverse nature. From table 1.2 we can see that, there is a huge difference between the performance of the two groups. From the data, it is clear that the rural sector is much isolated and the performance is quite poor in comparison to its urban counterpart. The average gross value added per worker (GVAW) in the urban area is Rs. 7350.5 whereas in the rural area it is much lower Rs. 3098.2. For all WOE, the average value of GVAW is around Rs. 5 thousand per Enterprises, which is much lower than its male counterpart ${ }^{5}$. However, we will not get into those aspects. Anyways, in the urban area, these micro and small-scale enterprises are integrated with the bigger informal firms or formal sector through subcontracting, putting out or any kind of contractual works. Through this linkages, urban informal enterprises are benefitted and performing well than rural enterprises. Contrarily, in the rural sector, the enterprises are isolated and deprived through

\footnotetext{
${ }^{5}$ Male Counterpart signifies the Men Owned Enterprises
} 
different social-economic-political forces. Despite that poor performance, WOE needs some more attention. In most of the cases, the male members are often encouraging the women to take the responsibility of the ownership for some specific reasons. Sometimes, to avail government benefits or facilities and enjoy the special assistantship. However, the biggest misery is that despite the ownership, the social voice of the women owner is still unheard. Male members of the family in both household and firm take all the major decisions.

However, from this discussion, a major question arises that, what are the probable factors that affecting the enterprise's performance? Here we have used some firm-specific, economic and social factors that are somehow affecting the performance of WOE. We have used a natural log of Gross Value Added per Worker as the dependent variable that indicates the firm's performance.

Table 1.4 Regression Result:

\begin{tabular}{|c|c|c|}
\hline Variable & Coefficient & $\begin{array}{c}\text { Robust } \\
\text { Standard Error } \\
\end{array}$ \\
\hline \multicolumn{3}{|c|}{ Dependent Variable: Log of GVA per Worker $(L N G V A W)$; R-squared: 0.588} \\
\hline Location of the Firm (Ref.: Within HH Premises) & $-0.731 * * *$ & 0.233 \\
\hline Account Maintenance (Ref.: Yes) & $0.259 * *$ & 0.110 \\
\hline Registration Status (Ref.: Yes) & 0.167 & 0.156 \\
\hline Work with Contract (Ref.: Yes) & $-1.110 * * *$ & 0.329 \\
\hline Total Labour & -0.036 & 0.024 \\
\hline Total Female Labour & $-0.077 * * *$ & 0.029 \\
\hline Years of Operation & -0.013 & 0.008 \\
\hline Total Emoluments & $0.000 * * *$ & 0.000 \\
\hline Loan Outstanding Amount & 0.000 & 0.000 \\
\hline Constant & $34.790 * *$ & 16.455 \\
\hline \multicolumn{3}{|l|}{$* * * p<0.01, * * p<0.05, * p<0.1$} \\
\hline
\end{tabular}

We have taken Natural log of Gross Value Added per workers as the response variable in a pure regression model and the explanatory variables are total labour of the enterprises, total female labour of the enterprises, years of operation of the enterprises, enterprise's total emoluments, enterprise's total loan outstanding amount along with four different dummy 
variables i.e. Location Dummy, Account dummy, Registration dummy and contract dummy and the result is depicted in table1.4.

From table 1.4, we can observe that total female labour, location dummy and contract dummy has a significant negative relation with the response variable whereas total emolument and account dummy both significantly positive relation. But loan outstanding, years of operation, total labour doesn't have any significant relation. Those who are operating their production process outside the household premises are performing well, again the enterprises who are not connected with any kind of contract work are eventually performing well. Again the coefficient of total emoluments tends to almost zero but it is significant, this is because in most of the enterprises are self-employed by nature. Years of operation of the enterprises are not significantly affected the firm's performances so, it can be inferred that WOE does not have any plan for further expansion, these are stagnant in nature.Thus from the above discussion, we can state that location of the enterprise, account maintenance, contract work, total female labour and total emolument of the enterprises are taking a pivotal role in the performance of the enterprises.

Women-owned Micro and small-scale enterprises have experienced many obstacles during their operation. There are several firm-economic-social-political impediments try to make the path difficult for women owner. Eventually, these difficulties affect the enterprise's performance. However, in this part, we are discussing only firm-specific problems for the WOE from the aforementioned microdata. From figure 2.1 we can see the major problems faced by the women entrepreneurs: 
Figure 2.1 Most Severe Problem face by the Women-Owned Enterprises

39.7

36

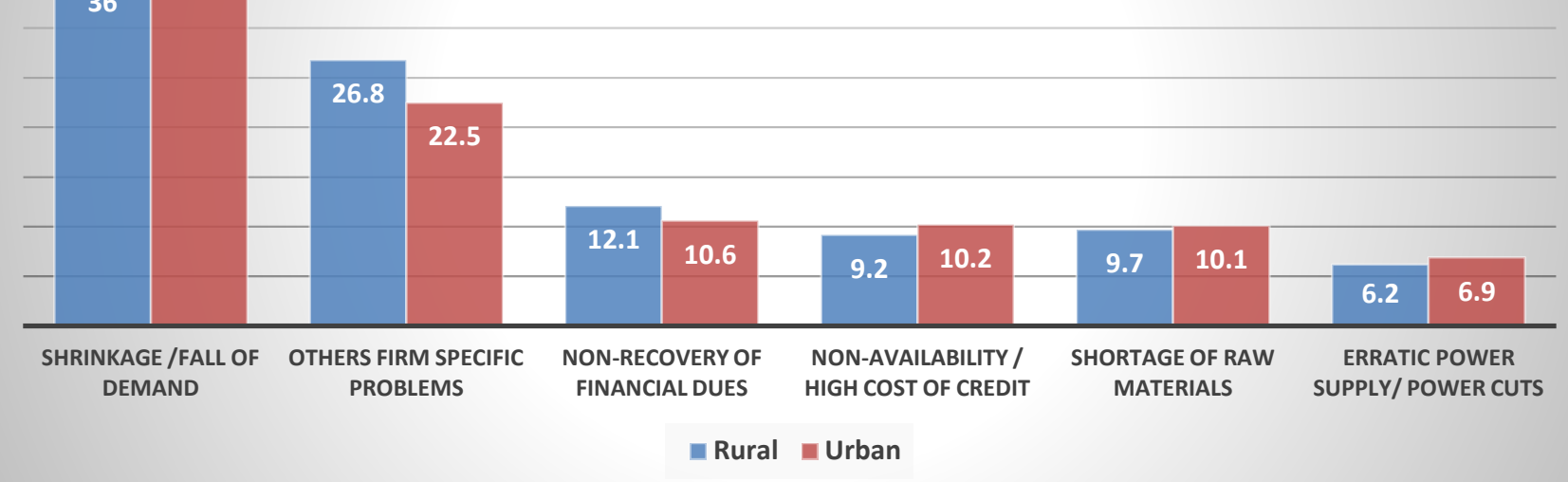

Estimated 1,23,85,129 Enterprises from a sample of 35,327 Women-Owned Unorganised Enterprises Source: computed from unit-level data of NSS 73rd Round (2015-16)

From the above figure, we can observe that the major problem which the women-owners generally faced is falling or shrinking demand of the output. Sometimes, the market demand may be the same or even higher but due to the lack of network with the other stakeholder in the output market causes the shrinkage of demand for enterprises. Non- recovery financial dues is also a very severe problem for this kind of enterprises. The main weakness of WOE that these enterprises are operating with the help of household labours and mostly they are women. Therefore, lack of market access and lack of mobility of the women-owner may cause nonrecovery financial dues from the market. Other problem like Non-availability/high cost of credit, Shortage or Raw materials, erratic power supply/power cut and some other firm-level problems also affects the enterprise's performance significantly.It is also observed that some women receive Self-help group loan or microcredit to invest the credit into her own enterprise and instead of doing that they spend it for household purposes and fail to repay to the respective bank. This activity may bring difficulties for a further loan. In the rural area, there is a major dominance of non-institutional loans like a moneylender. Once the entrepreneur is stuck into that trap, she is unable to get over from that never ended debt. 


\section{Conclusion}

Micro and small-scale enterprises have a huge variation in India across different aspects. In this diverse milieu, the performance of the WOE is also very much heterogeneous. The share of women is significantly lower in terms of ownership of micro and small-scale enterprises in India. In most of the cases, the male family members often encourage the woman member for being the owner of the enterprise just to get the opportunity of availing some specific government scheme or facilities. Mostly those WOEs, are home-based units and depend on the unpaid family labourers and the majority of the firms do not have any plan for further expansion and the central reason behind this is that the firms operate with an aim to just get a survival amount of livelihood. However, very few of WOE expand their plant size despite a lot of barriers. Among all WOEs, Other Backward Caste (OBC) Women are holding the major proportion of ownership, whereas socially backward communities like, SCs \& STs are still not sufficiently visible into the ownership. Although, the share of WOE are much lower in India, and its performance is also significantly poor. Despite the fact, the urban sector is performing much better in terms of the firm's gross value added per worker, whereas the rural sector is passing through an acute vulnerability.

The nature of WOEs is often varying in different circumstances. For this reason, the factors behind the diverse performance also deviate. There are several firm-economic-social factors affecting enterprises' performance. Microdata reveals a surprising result that, those who are not linked with contract works are performing much better. Therefore, it can be said that linkages with relatively bigger enterprises or formal sector is not taking a pivotal role for WOEs in the Indian scenario. In addition to this, the microdata reveals another result i.e. the female labour force in an enterprise is inversely related with its performance which implies as the number of women family labourers increases, the performance of the firm will be worsed, due 
to their partial involvement into the production process as they have to do the domestic works as well.

Although there are many firm-economic-social-political specific barriers that the women owners are facing while operating the production process but here we have considered the only firm related barriers for WOEs in India. Enterprises are suffering from the low or even falling demand of the products, non-recovery financial dues from the market, Shortage of raw materials are also a major problem for WOE. Along with this, other barriers are like the disruptive nature of power cut, non-availability of credit and other firm-level problems leads to the higher vulnerability of the enterprises. As, in this particular study, we have considered only firm-specific barriers but other socio-cultural barriers are not focused and hence there is further scope for investigation.

\section{Bibliography}

Agarwala, R. (2011). Informal labor, formal politics, and dignified discontent in India. Cambridge University Press. https://doi.org/10.1017/CBO9781139198738

Bushell, B. (2008). Women entrepreneurs in Nepal: What prevents them from leading the sector? Gender and Development, 16(3), 549-564. https://doi.org/10.1080/13552070802465441

Chen, M. A. (2011). Women in the Informal Economy: A global picture, the global movement. SAIS Review, 21(1), 71-82. Retrieved from http://www.cpahq.org/cpahq/cpadocs/module6mc.pdf

Elson, D., Bakker, I., Balakrishnan, R., Hoodbhoy, M., Keklik, H., Background, A. N., ... Gideon, J. (2000). Progress of the World's Women 2000 UNIFEM Biennial Report Coordinated Progress of the World's Women 2000 UNIFEM Biennial Report Publication Team and Advisory Committee. United Nations Development Fund for Women. Retrieved from http://iknowpolitics.org/sites/default/files/progress_of_the_world_s_women_2000.pdf

Ghosh, P., \& Cheruvalath, R. (2007). Indian female entrepreneurs as catalysts for economic growth and development. Entrpreneurship and Innovation, 8(2), 139-147. https://doi.org/10.5367/000000007780808048

Gurnani, P. S. (2014). Changing Status of Women-owned Enterprises in India-. Global Journal 
of Finance and Management, 6(9), 933-944. Retrieved from https://www.ripublication.com/gjfm-spl/gjfmv6n9_20.pdf

NCEUS. (2007). Report on Conditions of Work and Promotion of Livelihoods in the Unorganised Sector. Dolphin Printo Graphics (Vol. 53). https://doi.org/10.1017/CBO9781107415324.004

Paul GD, B., Achar, A. P., Muniyoor, K., \& Venkatesh Murthy, R. (2017). What determines the performance of small business units?: Insights from a jewellery cluster. Journal of Workplace Learning, 29(6), 447-472. https://doi.org/10.1108/JWL-02-2017-0016

Perwej, A. (2012). The Women Adoption in Owned Businesses and Entrepreneurship in India. International Journal of Emerging Trends \& Technology in Computer Science (IJETTCS), $\quad 1(4), \quad 56-61 . \quad$ Retrieved from https://www.ijettcs.org/Volume1Issue4/IJETTCS-2012-12-15-038.pdf

Sen, A. (2017). Commodities and Capabilities. Oxford University Press (1st ed., Vol. 91). Retrieved from https://scholar.harvard.edu/sen/publications/commodities-andcapabilities

Tambunan, T. (2009). Women entrepreneurship in Asian developing countries: Their development and main constraints. Journal of Development and Agricultiral Economics, 1(2), 27-40. Retrieved from http://www.africres.org/SMME Research/SMME Research General/Journal Articles/Women entrepreneurship in Asian developing countries.pdf

Timmons, J. and S. S. (2006). New Venture Creation: Entrepreneurship for the 21st Century. Singapore: McGraw-Hill. Retrieved from https://www.mheducation.com/highered/product/new-venture-creationentrepreneurship-21st-century-spinelli-adams/M9780077862480.accessibility.html

Unnikrishnan.P, S. B. (2016). a Study on the Issues and Problems of Women Entrepreneurs in Kerala With Special Reference To Malappuram District. International Jornal of Research Granthaalayah, 4(september). https://doi.org/10.5281/zenodo.158985 